\title{
Complete dislocation of the eye globe into the maxillary sinus: a rare case
}

\author{
Thanh Nam Nguyen, Thi Cam Van Bien, Minh Nguyet Duong \\ Department of Oculoplasty and Neuro-Ophthalmology, Ho Chi Minh City Eye \\ Hospital, Ho Chi Minh City, Vietnam
}

\begin{abstract}
Blowout fracture with entrapped orbital contents within the maxillary sinus is common due to the fragility of the inferior wall, but complete herniation of the eye globe is extremely rare and emergent. Dealing with such a case appears to be a real challenge for any ophthalmologist. We herein present a case of a 31-year-old woman with the entire eyeball missing from the orbit following a road traffic accident. Imaging revealed a complete herniation of the globe into the maxillary sinus. The patient underwent surgery for repositioning the herniated orbital contents and reconstructing the orbital walls. The outcome was satisfactory in terms of aesthetic effect, although the patient's vision could not be restored as it still depends on various factors, especially the survival of ganglion cells after trauma.
\end{abstract}

Keywords: blowout fracture, hernia, maxillofacial, orbital trauma, titanium mesh

\section{Introduction}

Orbital cavities are conical structures that resemble four-sided pyramids. Each orbit is made up of seven bones, forming four walls. With the medial wall and orbital floor being the thinnest, they are more prone to fracture following trauma. The orbit contains the globe, extraocular muscles, nerves, blood vessels, and fat. When being hit by a blunt object at high speed, the created force exerts equally on four walls and other orbital structures. Blowout fracture occurs as the medial or inferior wall breaks due to its vulnerability. Consequently, orbital contents prolapse into the maxillary sinus and posterior ethmoidal sinus. Depending on the severity of the injury, orbital structures can be partly or completely entrapped in the sinuses. The whole globe might fall into the maxillary sinus, abruptly tugging the optic nerve, making the central retinal artery stretched and twisted, destroying the blood supply to the optic nerve as a result. In that case, even if the eyeball is placed back into its original position, visual loss is almost inevitable. Kim and Baek reported that until 2005 there had only been three cases of intact eyeballs herniating into the maxillary sinus, only one of which had the globe completely

Correspondence: Thanh Nam Nguyen, MD, PhD, Ho Chi Minh City Eye Hospital, 280

Dien Bien Phu Street, Ward 7, District 3, Ho Chi Minh City, Vietnam.

E-mail: drthanhnam2020@gmail.com 
Table 1. Clinical profile of cases of traumatic globe dislocation into the maxillary sinus

\begin{tabular}{|c|c|c|c|c|c|c|c|}
\hline Authors & Eye & Etiology & $\begin{array}{l}\text { Time to } \\
\text { surgery }\end{array}$ & Approach & $\begin{array}{l}\text { Orbital } \\
\text { reconstructive } \\
\text { material }\end{array}$ & $\begin{array}{l}\text { Final visual } \\
\text { acuity }\end{array}$ & Ocular motility \\
\hline $\begin{array}{l}\text { Berkowitz } \\
\text { et al. } \\
(1981) 5\end{array}$ & OS & $\begin{array}{l}\text { Punched } \\
\text { with a } \\
\text { fist }\end{array}$ & $\begin{array}{l}\text { Same } \\
\text { day }\end{array}$ & Transantral & $\begin{array}{l}\text { Square silicone } \\
\text { implant }\end{array}$ & $\begin{array}{l}\text { Recovery; 20/20; } \\
\text { preserved VF }\end{array}$ & $\begin{array}{l}\text { Limited depression. } \\
\text { Retained motility in } \\
\text { other directions }\end{array}$ \\
\hline $\begin{array}{l}\text { Kim and } \\
\text { Baek } \\
(2005) 1\end{array}$ & OD & $\begin{array}{l}\text { Traffic } \\
\text { accident }\end{array}$ & $\begin{array}{l}\text { Same } \\
\text { day }\end{array}$ & $\begin{array}{l}\text { Transorbital } \\
\text { (transconjunctival) }\end{array}$ & $\begin{array}{l}\text { Porous } \\
\text { polyethylene }\end{array}$ & No & $\begin{array}{l}\text { Globe deviated to } \\
\text { superolateral position; } \\
\text { possible elevation and } \\
\text { abduction }\end{array}$ \\
\hline $\begin{array}{l}\text { Ramstead } \\
\text { et al. } \\
(2008) 6\end{array}$ & OS & $\begin{array}{l}\text { Stepped } \\
\text { on by a } \\
\text { bull }\end{array}$ & $\begin{array}{l}\text { Same } \\
\text { day }\end{array}$ & NA & Titanium mesh & $\begin{array}{l}\text { Recovery; } \\
20 / 200\end{array}$ & $\begin{array}{l}\text { Minimal horizontal } \\
\text { gaze; no vertical gaze }\end{array}$ \\
\hline $\begin{array}{l}\text { Damasceno } \\
(2010) 2\end{array}$ & OD & NA & $\begin{array}{l}\text { Same } \\
\text { day }\end{array}$ & Transantral & $\begin{array}{l}\text { Metallic plate } \\
\text { implant }\end{array}$ & $\begin{array}{l}\text { Recovery; 20/20; } \\
\text { preserved VF }\end{array}$ & $\begin{array}{l}\text { Retained abduc- } \\
\text { tion; loss in other } \\
\text { directions. }\end{array}$ \\
\hline $\begin{array}{l}\text { Zhang et al. } \\
(2012) 3\end{array}$ & OD & $\begin{array}{l}\text { Traffic } \\
\text { accident }\end{array}$ & $\begin{array}{l}\text { Same } \\
\text { day }\end{array}$ & & $\begin{array}{l}\text { Silastic } \\
\text { sheeting } \\
\text { implant }\end{array}$ & $\begin{array}{l}\text { Recovery; } 20 / 25 \\
\text { centrally; central } \\
\text { tunnel of vision }\end{array}$ & NA \\
\hline $\begin{array}{l}\text { Amaral } \\
\text { and Nery } \\
(2016) 4\end{array}$ & OS & $\begin{array}{l}\text { Struck } \\
\text { by gym } \\
\text { weight }\end{array}$ & 4 days & Transantral & Titanium mesh & Recovery; 20/50 & $\begin{array}{l}\text { Limited ocular motility } \\
\text { in all directions }\end{array}$ \\
\hline $\begin{array}{l}\text { Nguyen et } \\
\text { al. (2020) }\end{array}$ & OS & $\begin{array}{l}\text { Traffic } \\
\text { accident }\end{array}$ & 2 days & $\begin{array}{l}\text { Transorbital } \\
\text { (under the inferior } \\
\text { eyelid } 1.5 \mathrm{~mm} \text { ) }\end{array}$ & Titanium mesh & No; NLP & $\begin{array}{l}\text { Limited ocular motility } \\
\text { in all directions }\end{array}$ \\
\hline
\end{tabular}


entrapped within the sinus. ${ }^{1}$ In 2010, Damasceno reported a case of dislocation of the globe into the maxillary sinus, in which the patient had improved visual acuity with preserved visual field (VF) after surgery. ${ }^{2}$ By 2012 , the medical literature had recorded approximately 14 patients of ocular herniation, 8 of whom had partially restored vision. ${ }^{3}$ There has been no such report in Vietnam. At the Department of Oculoplasty and Neuro-Ophthalmology in Ho Chi Minh City Eye Hospital, for the first time, we successfully treated a blowout fracture with complete dislocation of the globe after trauma. The data from all previous relevant studies are presented in Table 1.

\section{Case report}

A 31-year-old woman was admitted following a road traffic accident. She fell and directly hit her face against a thick square piece of wood. The patient was rushed to the emergency room of a local health center with a bleeding left eye and no eyeball in the orbital cavity; hence, she was referred to Ho Chi Minh City Eye Hospital. On examination, her left eye had ptosis, upper eyelid laceration, and edema, and the globe went missing from the orbit (Fig. 1). Computed

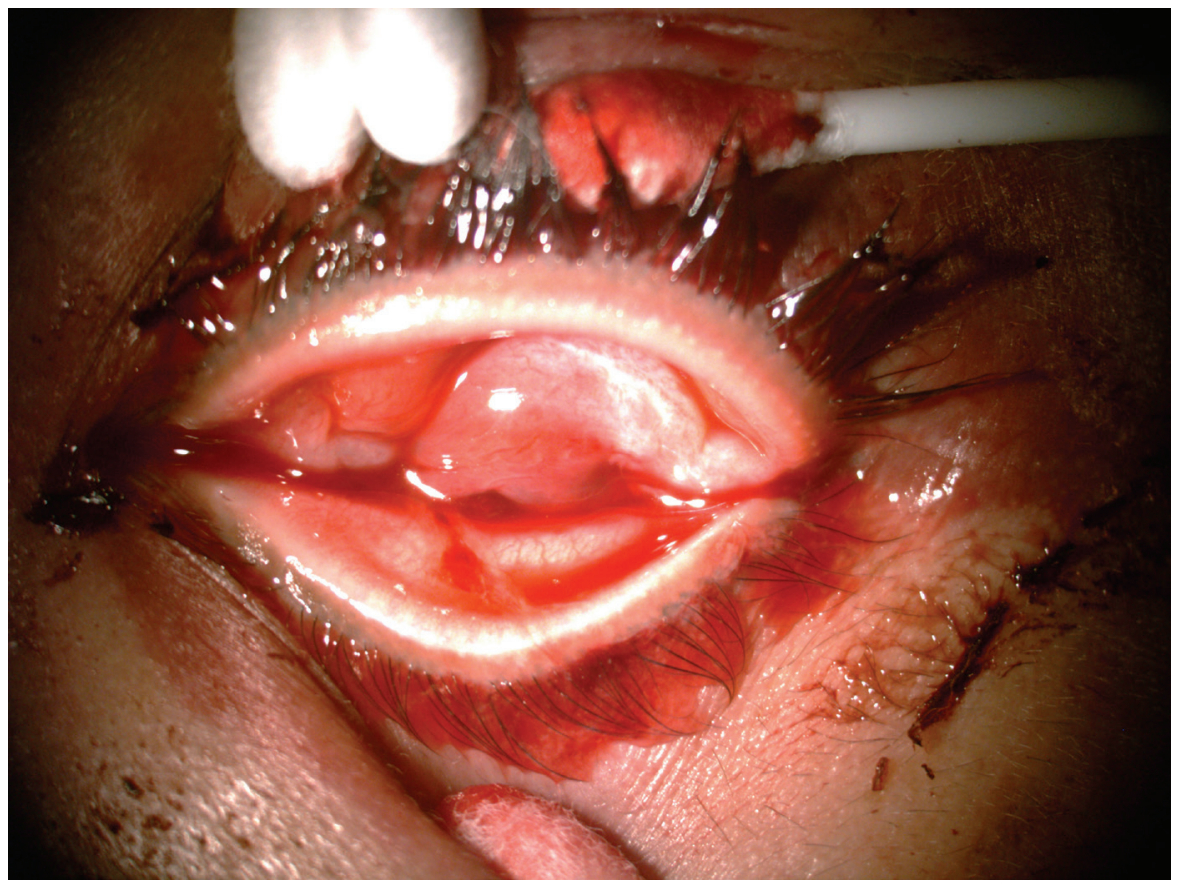

Fig. 1. The patient's condition at the time of hospital admission with missing globe from the orbit. 


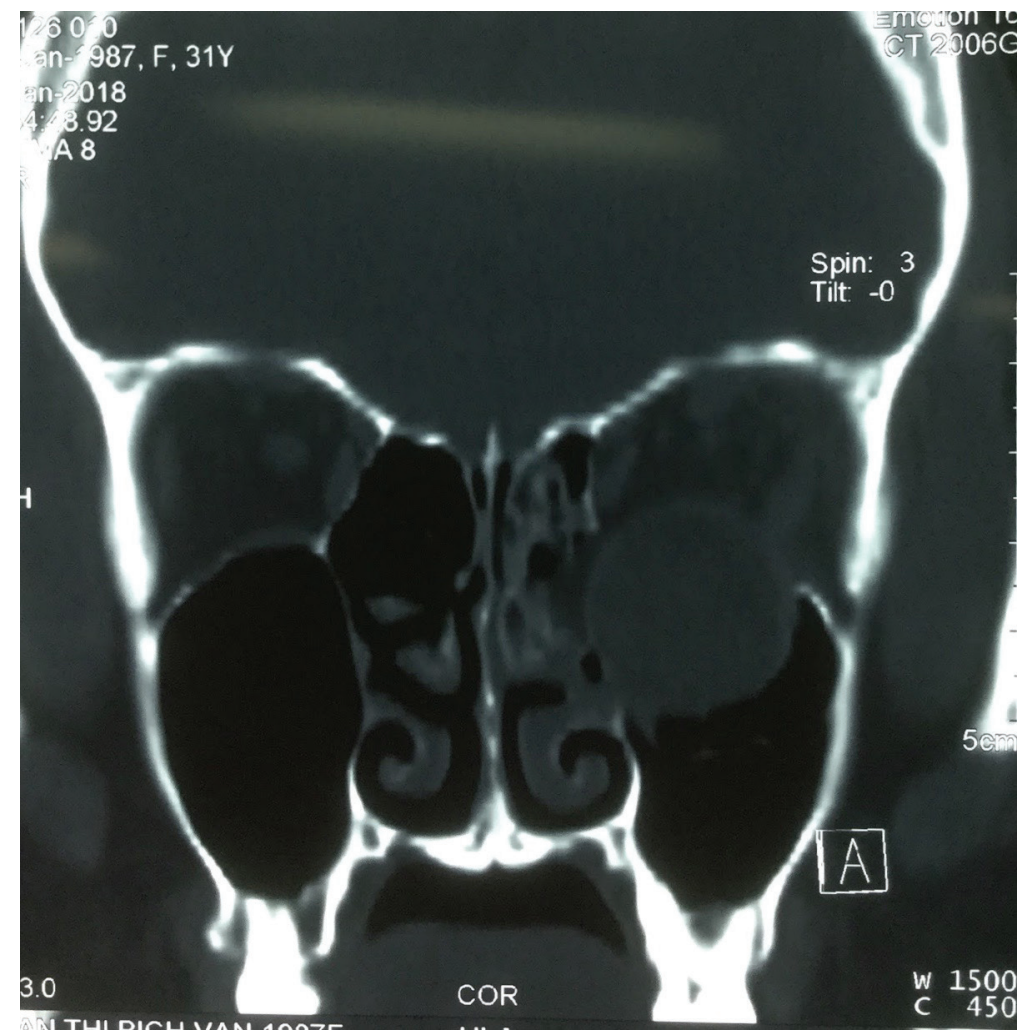

Fig. 2: Coronal sections of orbital computed tomography showed: Orbito-ethmoidal complex fractures, orbital floor fractures, with associated sinus effusion. No damage to the meninges, brain and skull. Normal right eye.

tomography scans, including coronal (Fig. 2) and sagittal (Fig. 3) planes, revealed complex orbital fractures with herniated orbital contents in the maxillary sinus and the optic nerve being tugged down by $25 \mathrm{~mm}$, respectively. the diagnosis was blowout fracture with complete dislocation of the left eye globe into the maxillary sinus following a road traffic accident.

We had a hospital consultation with an ear, nose, and throat specialist. A suggested treatment strategy for this case was to restore the globe to its original position, to reconstruct the orbital floor and orbital wall with a titanium mesh, and to use antibiotics and anti-inflammatory drugs for surgical prophylaxis and edema reduction, respectively. 


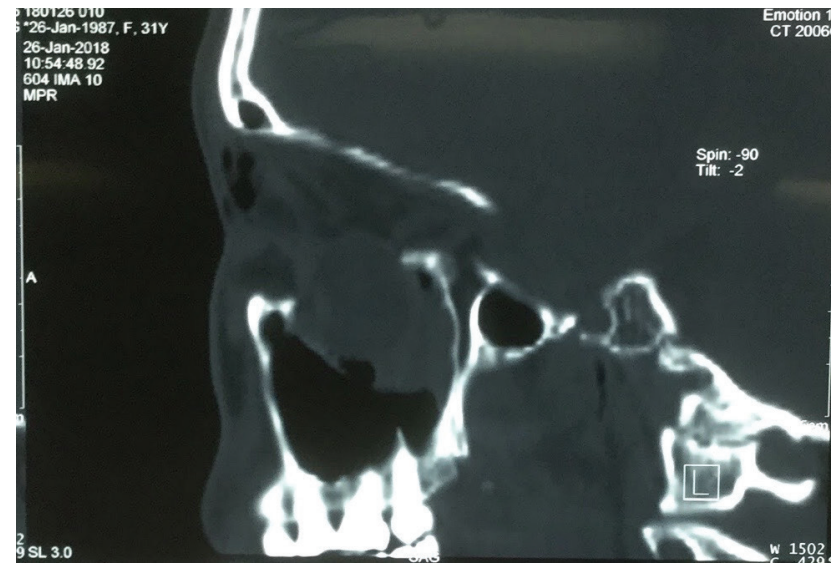

Fig. 3. Sagittal view showing an optic nerve bending down into the maxillary sinus.

\section{Surgical technique}

The patient underwent surgery under systemic anesthesia. In order to widen the surgical field of view and to leave room for flexible maneuvering, we made an incision $1.5 \mathrm{~mm}$ below the inferior eyelid to approach the orbital cavity. On the dissection along the orbital rim, we had to detach adhesive tissue to the orbital floor and medial wall as well as remove surrounding bone fragments for the protection of the eyeball when repositioning. To preserve the optic nerve, the globe was gently lifted with a spatula while avoiding meddling with the posterior pole. The entrapped globe was pushed in an upward and outward direction back from the maxillary sinus, returning it to its original position. The eyeball was fully intact but showed corneal abrasion. The extraocular muscles did not suffer any damage. Subsequently, we restored the orbital floor and medial wall with titanium mesh, then repaired the eyelid lacerations.

\section{Postoperative assessment}

At postoperative day 1 , the left eye showed complete ptosis, chemosis, diffuse subconjunctival hemorrhage, corneal abrasion, 5-mm pupil, negative direct pupillary reflex, positive RAPD, limited ocular motility in all directions (- 4), posterior pole retinal hemorrhage, grade 1 disc edema, and no light perception. On postoperative day 5 (Fig. 4), visual acuity had not improved. However, swelling of the eyelid had reduced, ptosis subsided from complete ptosis to grade 2, chemosis had reduced, corneal epithelium was healing, ocular motility improved from -4 to -2 , and retinal hemorrhage still existed with grade 1 disc edema. The patient was satisfied with the outcome. On postoperative week 2 (Fig. 5), the patient still had enophthalmos, but other signs had recovered significantly. The eye had light perception. 


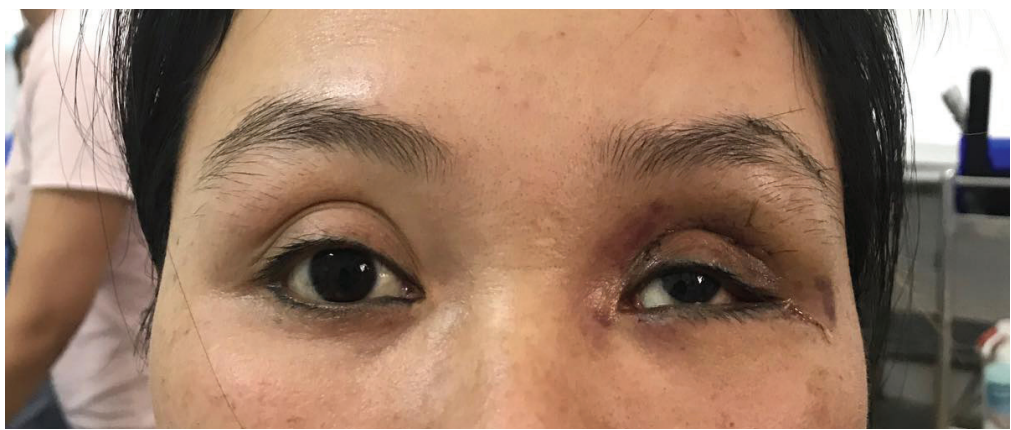

Fig. 4. Clinical examination on day 5 postoperative showed improvement of the patient's physical appearance with subsided ptosis and edema.

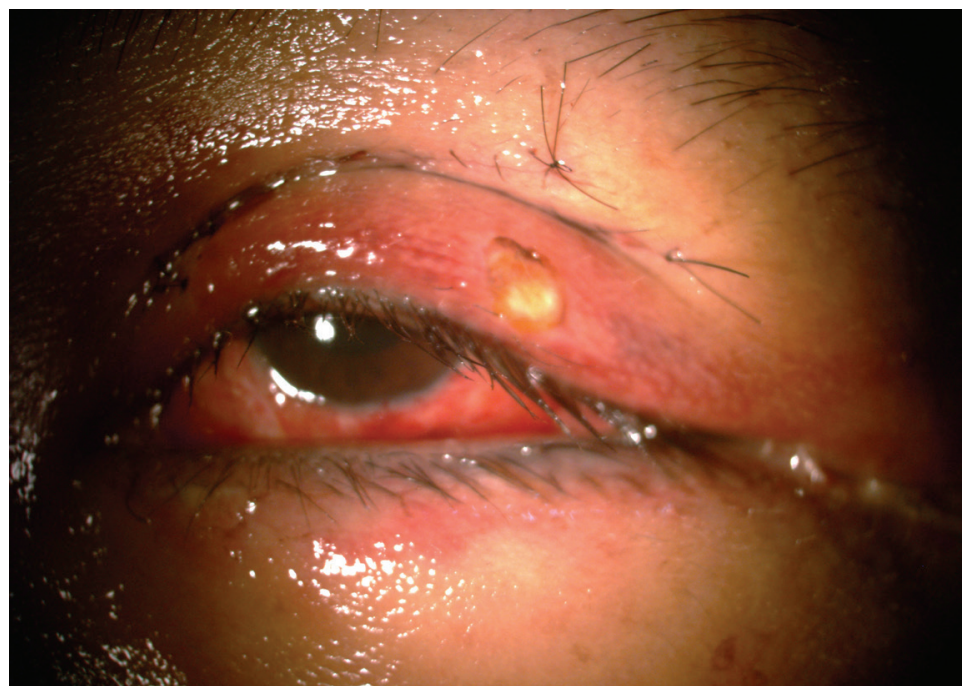

Fig. 5. Clinical examination 2 weeks postoperatively showed significant recovery of the patient.

\section{Discussion}

Complete dislocation of the globe into the maxillary sinus through blowout fracture is a very rare ophthalmic emergency. Ischemia of ocular and other herniated orbital contents follows immediately. Therefore, intervention is required within the first few hours for those structures to be released. The patient must therefore present early and must be operated by a skilled oculoplastic and orbital surgeon. In this case, however, the patient was operated on her second day after trauma. At that time, the ischemia had lasted too long for vision to be restored. The etiology for permanent visual loss could be inferred as traumatic optic neuropathy 
due to the sudden distortion of the optic nerve, as the twist and stretch of the central retinal artery behind the lamina cribrosa destroyed the blood supply to the optic nerve. The longer the time to surgery takes, the higher the risk of complications due to edema compressing nearby structures, especially the optic nerve and blood vessels, aggravating the vicious cycle of ischemia. ${ }^{4}$ Recovery of vision depends greatly on the severity of the injury, timely intervention, and most importantly, the survival of ganglion cells following trauma, regardless of the surgeon's attempt in returning the eyeball to its original position. $\cdot^{3-6}$ For that reason, early diagnosis, and intervention to minimize the time lost and to limit the damage caused are crucial to help preserve the patient's vision.

There are two surgical approaches to release entrapped orbital contents recommended in the medical literature: the transorbital and the transantral approach. ${ }^{4}$ The surgeon will choose the most appropriate route, contingent on their proficiency. Having experienced many cases of restructuring orbital wall, we chose the transorbital approach due to its familiarity and to minimize damage for the patient. At that time, the edematous herniated contents made it impossible to be put back through the original pathway. After dissecting through the periosteum, we had to remove sharp bone fragments for the enlargement of an already existing hole created by trauma. Consequently, the globe and its associated structures were lifted successfully without being damaged.

Once the prolapsed structures had been brought back in place, we still had to reform bony orbital defects for them to be fixed in the cavity. Many reconstructive materials have been described in the literature, such as iliac crest autografts or mesh made of silicon, ceramic, titanium, polyethylene, etc. We chose a titanium mesh for this case because of its solidity and malleability. The implant can be molded along the orbital wall accurately and can be fixated with self-drilling bone screws. Other herniated tissue became so swollen that other reconstructive materials would not have been able to endure.

\section{Conclusion}

Dislocation of the globe into the maxillary sinus is an extreme situation. Recovery of vision depends on the severity of injury, partial or complete herniation of the eyeball, early diagnosis and intervention, and most importantly, the survival of ganglion cells following trauma. If the optic nerve can still function, with early diagnosis and intervention vision can be restored. Conversely, even if late hospital admission with optic nerve distortion has already caused irreversible loss of vision, we should still proceed to operate with the aim of returning all orbital herniated contents to their original position, ensuring a positive cosmetic and psychological effect for the patient. 


\section{Declarations}

\section{Informed consent}

The patient provided informed consent for the use of the clinical information and images contained in this case report.

\section{Competing interests}

None to declare.

\section{Funding}

None to declare.

\section{Acknowledgements}

None to declare.

\section{References}

1. Kim S, Baek S. Traumatic dislocation of the globe into maxillary sinus associated with extraocular muscle injury. Graefes Arch Clin Exp Ophthalmol. 2005;243(12):1280-1283.

2. Damasceno NA, Damasceno EF. Traumatic orbital fracture with intact ocular globe displacement into the maxillary sinus. Rev Bras Oftalmol. 2010;69(1):52-54.

3. Zhang-Nunes SX, Jarullazada I, Mancini R. Late central visual recovery after traumatic globe displacement into the maxillary sinus. Ophthalmic Plast Reconstr Surg. 2012;28(1):e17-e19.

4. Amaral MB, Nery AC. Traumatic globe dislocation into the paranasal sinuses: Literature review and treatment guidelines. J Craniomaxillofac Surg. 2016;44(5):642-647.

5. Berkowitz RA, Utterman AM, Patel DB. Prolapse of the globe into the maxillary sinus after orbital floor fracture. Am J Ophthalmol. 1981;91(2):253-257.

6. Ramstead C, McCabe J, Alkahtani M, Leong-Sit J, Morhart M. Traumatic dislocation of the globe into the maxillary sinus. Can J Ophthalmol. 2008;43(3):364-366. 